\title{
METODE REWARD AND PUNISHMENT PADA PEMBELAJARAN PROBING PROMPTING TERHADAP KEMAMPUAN PEMECAHAN MASALAH
}

\author{
Rizky Novalinda ${ }^{1}$, Ali Syahbana ${ }^{2}$, Ety Septiati ${ }^{3}$ \\ 1,2,3 FKIP, Universitas PGRI Palembang \\ Email korespondensi : syahbanaumb@yahoo.com
}

Diterima : (31-05-2020), Revisi: (04-11-2020), Diterbitkan : (24-12-2020)

\begin{abstract}
ABSTRAK
Penelitian ini berfokus pada upaya untuk mengetahui pengaruh metode Reward and Punishment pada pembelajaran Probing Prompting terhadap kemampuan pemecahan masalah matematis siswa. Penelitian ini adalah penelitian eksperimen, dengan populasi siswa kelas X SMK PGRI 2 Palembang. Sampel penelitian ini adalah siswa kelas X TO 4 sebanyak 31 siswa dan siswa kelas X TO 6 sebanyak 22 siswa. Instrumen yang digunakan adalah tes kemampuan pemecahan masalah. Analisis data menggunakan independent sample t test dan analisis dokumen tertulis hasil tes siswa. Dari hasil penelitian disimpulkan bahwa ada pengaruh kemampuan pemecahan masalah siswa yang menggunakan pembelajaran Probing Prompting dengan Reward and Punishment dibandingkan dengan pembelajaran Probing Prompting tanpa Reward and Punishment.
\end{abstract}

Kata kunci : Reward, Punishment, Probing Prompting, Pemecahan masalah

\section{ABSTRACT}

This study focused on efforts to determine the effect of the Rewarding and Punishment method in Probing Prompting learning of students' mathematical problem solving abilities. This study was an experimental study, with a population of class X students at SMK PGRI 2 Palembang. The sample of this research was students of class X TO 4 by 31 students and students of class X TO 6 by 22 students. The instrument used was a test of problem solving ability. The data analysis was using independent sample t test and analysis of written documents on student test results. From the results of the study could be concluded that there was an influence of students' problem solving abilities by using Probing Prompting learning with Rewarding and Punishment compared to Probing Prompting learning without Reward and Punishment.

Keywords: Rewarding, Punishment, Probing Prompting, Problem Solving 


\section{Pendahuluan}

Pendidikan merupakan hal fundamental dan harus dijalani oleh setiap orang agar tidak menjadi budak masa depan. Pendidikan yang layak akan membantu membentuk karakter anak bangsa dan mengembangkan kemampuan mereka agar terciptanya generasi yang berkualitas.

Secara formal, proses pendidikan anak banyak dilakukan di sekolah. Walaupun ada banyak pendidikan non formal, namun pendidikan formal lebih tertata dan mengacu pada kurikulum yang jelas dan terukur, sehingga dapat menghasilkan outcome yang berkualitas. Dengan demikian, keberhasilan siswa sangat ditentukan oleh proses belajar-mengajar di kelas.

Proses belajar-mengajar tidak terlepas dari peran seorang guru dalam menyalurkan ilmu pengetahuan dan membimbing peserta didik. Di sinilah dituntut kepiawaian seorang guru dalam mengelola materi dan peserta didiknya, guru yang mampu mengusai keduanya akan dapat menghasilkan pembelajaran yang berkualitas terutama untuk pelajaran matematika.

Matematika merupakan salah satu disiplin ilmu yang perlu diperhatikan karena tergolong sebagai salah satu pelajaran yang aplikasinya sangat banyak dalam kehidupan sehari-hari, terutama untuk memecahkan berbagai masalah perhitungan dan pengukuran. Namun, masih banyak yang menganggap matematika sebagai pelajaran yang sulit dan membosankan.

Pemecahan masalah matematika telah menjadi tema utama dalam penelitian dan kurikulum seluruh dunia (Torner, Schoenfeld, \& Reiss, 2007), termasuk juga di Indonesia. Setiap belajar matematika, walaupun ada kemampuan lain yang dilihat juga, misalnya berpikir kritis, berpikir kreatif, pemahaman konsep, dan lain sebagainya, tetap saja muaranya pada pemecahan masalah.

Dalam standar isi pada Permendiknas No. 22 Tahun 2006 dinyatakan juga bahwa kemampuan memecahkan masalah matematika yang meliputi kemampuan memahami masalah, merancang model matematika, menyelesaikan model, danmenafsirkan solusi yang diperoleh adalah salah satu dari tujuan mata pelajaran matematika. Namun menurut Harahap dan Surya (2017:45), salah satu kemampuan yang masih kurang dimiliki peserta didik terutama peserta didik di Indonesia adalah pemecahan masalah matematis.

Begitu juga kondisi siswa kelas X SMK PGRI 2 Palembang, kemampuan pemecahan masalah matematis mereka masih kurang. Guru-guru yang mengajar matematika di kelas X menyampaikan bahwa siswa masih kurang mampu dalam memahami cerita kontekstual, sehingga cukup susah untuk membuat model matematika dan menyelesaikannya. Di sekolah ini juga, gurunya belum terbiasa memberikan soal-soal pemecahan masalah yang levelnya lebih tinggi untuk 
dikerjakan siswanya. Gambaran kondisi siswa di SMK PGRI 2 Palembang ini mewakili gambaran kebanyakan sekolah di Indonesia.

Menurut Sumartini (2016) untuk meningkatkan kemampuan pemecahan masalah siswa, perlu didukung oleh metode pembelajaran yang tepat. Dalam mengasah kemampuan pemecahan masalah matematis siswa sangat diperlukan model pembelajaran yang mendukung dan memacu motivasi siswa dalam belajar, salah satunya adalah model pembelajaran probing prompting. Probing prompting adalah pembelajaran dengan menyajikan serangkaian pertanyaan yang sifatnya menuntun dan menggali gagasan siswa sehingga dapat melejitkan proses berpikir yang mampu mengaitkan pengetahuan dan pengalaman siswa dengan pengetahuan baru yang sedang dipelajari (Huda, 2014: 281). Pembelajaran probing prompting sangat erat kaitannya dengan pertanyaan. Pertanyaan-pertanyaan yang dilontarkan pada saat pembelajaran ini disebut probing question. Probing question adalah pertanyaan yang bersifat menggali untuk mendapatkan jawaban lebih dalam dari siswa yang bermaksud untuk mengembangkan kualitas jawaban, sehingga jawaban berikutnya lebih jelas dan akurat dan beralasan.

Salah satu faktor pendukung terlaksananya model pembelajaran probing prompting adalah kelas yang memiliki siswa-siswi yang aktif selama pembelajaran, dalam hal ini kesuksesan pelaksanaan pembelajaran probing prompting ditentukan oleh siswa yang aktif. Namun sayangnya, bahwa model probing prompting memiliki kelemahan dari segi keaktifan siswa ini, yaitu siswa akan merasa takut jika guru kurang bisa menciptakan suasana kelas yang akrab, karena pada umumnya siswa akan panik terlebih dulu jika akan diberikan pertanyaan. Selain itu, akan menghabiskan waktu jika dua atau tiga orang siswa tidak dapat menjawab pertanyaan yang diberikan. Dengan kata lain, suasana selama model pembelajaran ini akan terasa kaku jika guru kurang bisa mengendalikan kelas dan mengatur waktu (Shoimin, 2014:127).

Untuk itu guna menutupi kelemahan dalam model probing prompting ini dicoba untuk melengkapinya dengan memberikan metode reward and punishment. Metode reward and punishment adalah metode pembelajaran yang menerapkan pemberian hadiah jika siswa mampu dan pemberian hukuman jika siswa tidak mampu menyelesaikan tugas yang diberikan guru. Menurut Purnomo dan Abdi (2012) reward dimunculkan untuk memotivasi seseorang karena ada anggapan bahwa dengan memberikan hadiah atas perilaku baik dan hasil pekerjaannya, ia akan mempertahankan perilaku baiknya dan bekerja lebih maksimal. Apalagi jika hadiah yang diberikan cukup menggiurkan. Sedangkan punishment dimunculkan untuk memotivasi seseorang agar tidak melakukan kesalahan dalam melakukan sesuatu. Kedua bentuk motivasi ini tidak bisa dikatakan mana yang benar dan 
mana yang salah. Tetapi lebih cocok jika dilihat dari baik dan buruknya, bukan benar atau salahnya.

Pemberian hadiah sebagai motivasi pembangkit semangat untuk berprestasi dan pemberian hukuman agar siswa lebih cermat dan teliti. Pemberian hadiah dapat berupa penambahan nilai pada segi keaktifan atau pada hasil tes dan lain sebagainya, sedangkan pemberian hukuman dapat berupa pengerjaan beberapa soal matematika atau membuat rangkuman materi dan lain sebagainya. Sehingga diharapkan dengan adanya penambahan dari metode pembelajaran reward and punishment pada model pembelajaran probing prompting akan menciptakan suasana kelas yang menyenangkan, jika suasana kelas menyenangkan siswa lebih mampu menerima pelajaran dan tidak ditekan oleh rasa takut. Waktu yang digunakan selama proses pembelajaran pun tidak akan terbuang, karena siswa akan lebih aktif jika ada yang memacu mereka untuk belajar terutama jika diberi penghargaan dan berusaha menjawab pertanyaan dengan baik karena adanya pemberian hukuman.

Menurut hasil penelitian Triningsih (2018) bahwa penggunaan metode reward dan punishment dengan model pembelajaran kooperatif tipe STAD berpengaruh terhadap motivasi dan hasil belajar matematika siswa kelas VII SMP Negeri 13 Makassar, motivasi dan hasil belajar siswa akan lebih baik jika diberi reward dan punishment. Penelitian Prasetyo dkk (2019) juga menyimpulkan bahwa pemberian reward dan punishment membuat siswa antusias dan termotivasi dalam pembelajaran matematika.

Dengan demikian, penerapan model pembelajaran probing prompting disertai dengan reward and punishment perlu dilakukan sebagai salah satu cara dalam meningkatkan kemampuan pemecahan masalah matematis siswa. Pemberian reward dan punishment memang diperlukan untuk menambah semangat siswa dalam memecahkan masalah matematika.

Berdasarkan latar belakang seperti yang telah diuraikan, maka penelitian ini bertujuan untuk mengetahui pengaruh metode reward dan punishment pada pembelajaran Probing Prompting terhadap Kemampuan Pemecahan Masalah Matematis Siswa kelas X SMK PGRI 2 Palembang.

\section{Metode Penelitian}

Penelitian ini dilakukan di kelas X TO SMK PGRI 2 Palembang yang berlokasi di Jalan Saptamarga Kecamatan Kalidoni tahun ajaran 2018/2019. Populasi penelitian ini adalah siswa kelas X TO yang berjumlah 185 siswa, sedangkan sampel penelitiannya adalah siswa kelas X TO 4 sebanyak 31 orang dan siswa kelas 
X TO 6 sebanyak 22 orang.

Penelitian yang dilakukan merupakan penelitian eksperimen. Rancangan perlakuan dalam penelitian ini adalah Posttest-Only Control Design, dengan dua kelompok yang masing-masing dipilih secara random (Sugiyono, 2017:112). Pemilihan secara random dilakukan agar tidak terjadi pilih kasih dalam menentukan sampel, sehingga sampel yang terpilih memang representasi dari populasinya. Kelompok pertama diberi perlakuan (X) dan kelompok yang lain tidak.

$\begin{array}{lll}\mathrm{R} & \mathrm{X} & \mathrm{O}_{2} \\ \mathrm{R} & & \mathrm{O}_{4}\end{array}$

Keterangan:

$\mathrm{R}$ : sampel acak

$\mathrm{X}$ : perlakuan

$\mathrm{O}_{2}$ : Postes kelas eksperimen

$\mathrm{O}_{4}$ : Postes kelas kontrol

Alat pengumpulan data yang digunakan yaitu instrumen tes berupa 5 buah soal tes akhir pada materi peluang. Soal tes akhir ini telah divalidasi oleh ahli yang berkompeten dan juga telah diujicoba terlebih dulu, sehingga instrumen ini dinyatakan valid, reliabel, memiliki tingkat kesulitan yang sedang, dan mempunyai daya beda yang cukup baik. Analisis data dalam penelitian ini berupa Uji Independent Sample t-Test dengan uji prasyarat yaitu, Uji Normalitas dan Uji Homogenitas.

Prosedur kerja dalam penelitian ini dilaksanakan dengan tiga tahapan, yaitu tahap perencanaan, tahap pelaksanaan dan tahap pelaporan. Tahap pelaksanaan terdiridari empat kali pertemuan.

\section{Hasil dan Pembahasan}

Pembelajaran probing prompting dengan reward and punishment yang telah dilaksanakan mengikuti langkah-langkah sebagai berikut: (1) Guru mengajukan pertanyaan yang sifatnya menggali pola pikir siswa dan menuntun ke arah jawaban dari pertanyaan tersebut sehingga terjadilah proses berpikir yang mengaitkan pengetahuan siswa dan pengalamannya dengan pengetahuan baru yang sedang dipelajari, guru memberikan masalah sebagai probing untuk menggali 
pengetahuan atau pengalaman siswa agar bisa dikaitkan dengan pengetahuan baru yang akan siswa pelajari; (2) Siswa diberikan waktu untuk menjawab, siswa didorong (prompting) agar mampu memberikan jawaban yang tepat; (3) Guru mengoreksi jawaban siswa, melalui pemberian kesempatan kepada siswa lain untuk menanggapi hasil pekerjaan temannya. Dalam sebuah diskusi, tidak menutup kemungkinan jika ada beberapa siswa yang pasif. Untuk itu, agar siswa tersebut ikut berpartisipasi maka diberikan kesempatan kepada kelompok lain untuk menanggapi; (4) Guru memberikan reward/punishment kepada siswa sesuai dengan hasil yang diperoleh siswa.Reward (penghargaan) diberikan sebagai bentuk apresiasi bagi siswa yang mampu menyelesaikan permasalahan, dengan catatan penyelesaian yang dilakukan oleh siswa tersebut memang tepat dan sesuai dengan indikator kemampuan pemecahan masalah matematis. Sedangkan bagi siswa yang belum mampu atau kurang dalam menyelesaikan permasalahan tersebut, maka guru akan memberikan Punishment (hukuman) berupa mengerjakan latihan di rumah atau merangkum materi yang dipelajari hari itu.

Data hasil postes dari 53 siswa terkait penerapan probing prompting dengan reward and punishment dan probing prompting saja sebagai berikut:

Tabel 1. Statistik Deskriptif Nilai Postes Siswa

\begin{tabular}{ccc}
\hline \multirow{2}{*}{ Statistik } & \multicolumn{2}{c}{ Kelas } \\
\cline { 2 - 3 } & Eksperimen & Kontrol \\
\hline $\mathrm{N}$ & 31 & 22 \\
\hline Rata-rata & 86 & 76 \\
\hline Standar & 51,86 & 45,56 \\
Deviasi & & \\
\hline Median & 86 & 74,5 \\
\hline Modus & 82 & 75 \\
\hline Xmax & 100 & 89 \\
\hline Xmin & 80 & 70 \\
\hline
\end{tabular}

Berdasarkan tabel 1 di atas menunjukkan bahwa nilai rata-rata hasil tes akhir pada kelas eksperimen yang diberi perlakuan dengan model pembelajaran probing prompting dengan reward and punishment lebih tinggi dibandingkan dengan nilai rata-rata hasil tes akhir pada kelas kontrol yang diberi pembelajaran probing prompting saja. 
Lalu dilanjutkan uji prasyarat. Uji Normalitas data menggunakan Uji Kolmogorov-Smirnov atau Uji Lilliefors dengan menggunakan program SPSS 24 For Windows. Data berdistribusi normal apabila nilai signifikan $>\alpha=0,05$. Berikut ini ditampilkan hasil Uji Normalitas menggunakan Uji Kolmogorov-Smirnov.

Tabel 2. Hasil Uji Normalitas Data

\begin{tabular}{lccccccc}
\multicolumn{1}{c}{ Tests of Normality } \\
\hline & Model & Solmogorov-Smirnova & \multicolumn{3}{c}{ Shapiro-Wilk } \\
\cline { 3 - 8 } & Statistic & Df & Sig. & $\begin{array}{c}\text { Sta- } \\
\text { tistic }\end{array}$ & df & Sig. \\
\hline $\begin{array}{l}\text { Kemampuan } \\
\text { pemecahan } \\
\text { masalah }\end{array}$ & PP dgn RP & .070 & 31 & $.200^{*}$ & .957 & 31 & .247 \\
\hline
\end{tabular}

a. Lilliefors Significance Correction

Berdasarkan tabel 2 di atas nilai signifikan kelas eksperimen dan kelas kontrol sebesar 0,200 dengan nilai $\alpha=0,05$, karena 0,200 $>0,05$ maka nilai kemampuan pemecahan masalah matematis siswa kelas eksperimen dan kelas kontrol diambil dari populasi yang berdistribusi normal. Dengan demikian dapat disimpulkan bahwa data yang diambil untuk kelas eksperimen dan kelas kontrol berdistribusi normal.

Analisa yang digunakan untuk menguji homogenitas variabel dalam penelitian ini menggunakan program SPSS 24 For Windows yaitu dengan Uji Levene Statistic. Pengambilan keputusan dengan taraf signifikan $5 \%(\alpha=0,05)$, jika nilai signifikan $\geq 0,05$ maka Ho diterima, artinya varians sampel dinyatakan homogen. Pada tabel di bawah ini ditampilkan hasil uji homogenitas menggunakan Uji Levene Statistic.

Tabel 3. Hasil Uji Homogenitas Data

\begin{tabular}{cccc}
\hline \multicolumn{5}{c}{ Kemampuan Pemecahan Masalah Matematis Siswa } \\
\hline Levene Statistic & df1 & df2 & Sig. \\
\hline .001 & 1 & 51 & .981 \\
\hline
\end{tabular}

Berdasarkan tabel 3 di atas nilai signifikan adalah 0,981 dengan $\alpha=0,05$ karena 0,981> 0,05 maka varians dari dua kelas adalah homogen. Oleh karena itu data ini dapat dilanjutkan analisisnya.

Dilanjutkan pengujian data dengan menggunakan Uji Independent Sample t Test yang menggunakan program SPSS 24 dan hasilnya sebagai berikut. 
Tabel 4. Hasil Uji Independent Sampel t Test

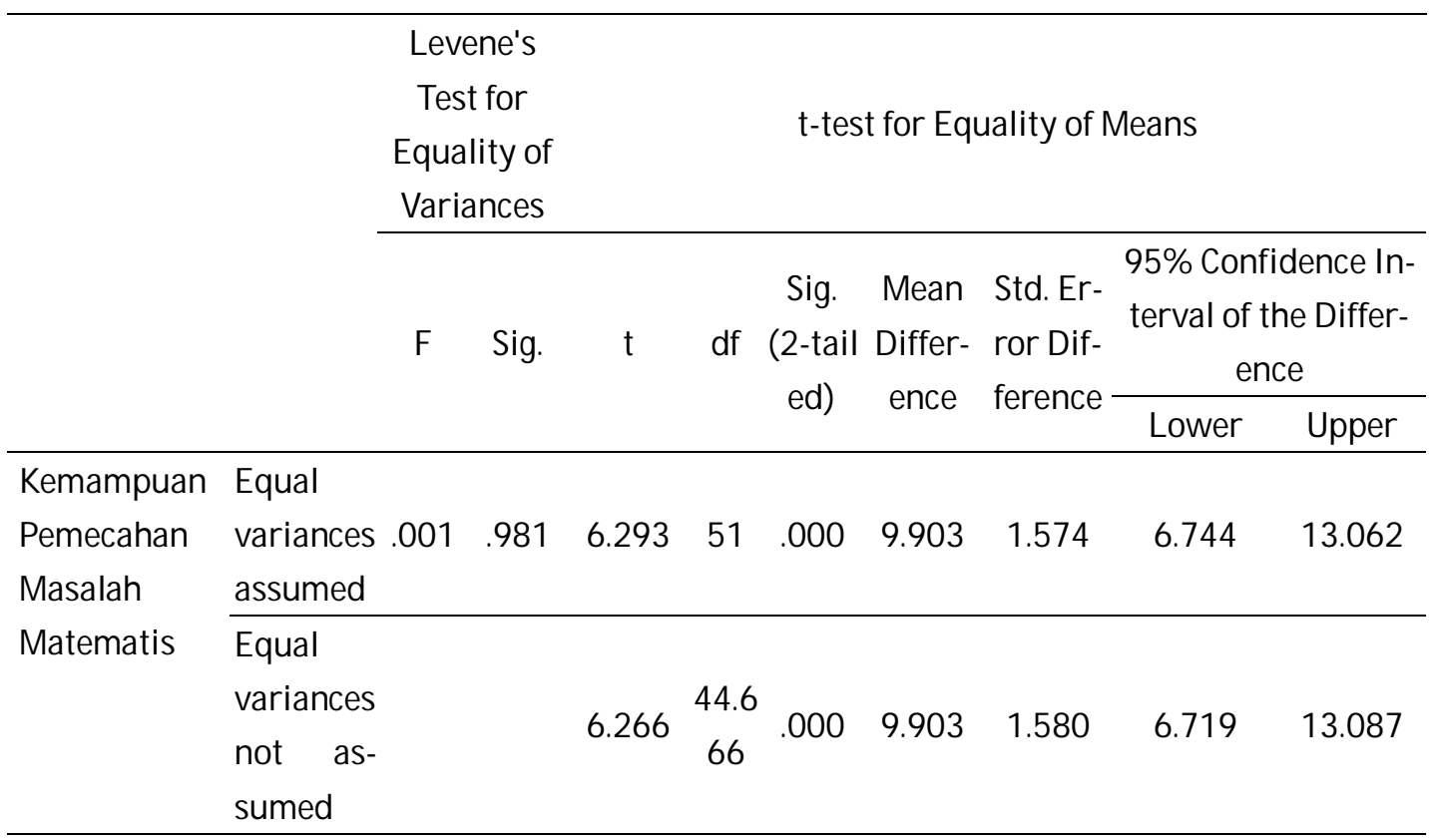

Berdasarkan hasil perhitungan di atas diperoleh nilai sig $(p)=0,000$. Karena nilai $\mathrm{p}<0,025$, maka dapat disimpulkan bahwa terdapat pengaruh reward and punishment pada pembelajaran probing prompting terhadap kemampuan pemecahan masalah matematis siswa kelas X SMK PGRI 2 Palembang.

Selanjutnya, dari tes yang diberikan tersebut, jawaban dianalisis untuk menghitung nilai rata-rata tiap indikator kemampuan pemecahan masalah matematis siswa.Berikut ini ditampilkan perbandingannya antara kelas eksperimen dan kelas kontrol.

Tabel 5. Nilai Rata-rata Kemampuan Pemecahan Masalah Matematis Siswa Per-indikator Pada Soal Postes

\begin{tabular}{rlcc}
\hline No & \multicolumn{1}{c}{ Indikator } & Kelas Eksperimen & Kelas Kontrol \\
\hline 1. & $\begin{array}{l}\text { Mencari dan menuliskan informasi } \\
\text { yang diketahui dan ditanyakan }\end{array}$ & 98 & 97 \\
\hline 2. & $\begin{array}{l}\text { Membuat rencana penyelesaian ma- } \\
\text { salah matematika }\end{array}$ & 98 & 98 \\
\hline 3. & $\begin{array}{l}\text { Menerapkan rencana penyelesaian } \\
\text { masalah matematika }\end{array}$ & 88 & 72 \\
\hline 4. & Memeriksa kembali & 68 & 38 \\
\hline & Rata-rata & 86 & 76 \\
\hline
\end{tabular}


Dari tabel 5 dapat dilihat bahwa kemampuan pemecahan masalah matematis siswa tertinggi dalam penelitian ini adalah pada indikator 1 (98) dan indikator 2 (98) serta indikator 3 (88). Tingginya nilai indikator kemampuan pemecahan masalah matematis 1, 2 dan 3 disebabkan oleh diterapkannya model pembelajaran probing prompting dengan reward and punishment, karena salah satu kelebihan model pembelajaran probing prompting adalah dapat meninjau kembali materi lampau sehingga siswa akan lebih memahami masalah dan pandai dalam melaksanakan pemecahan masalah. Dan tidak lupa juga pemberian reward and punishment yang membuat siswa lebih seksama dalam setiap langkah-langkah penyelesaian masalah sehingga meminimalisir kurangnya salah satu langkah penyelesaian, hal ini karena salah satu kelebihan reward and punishment adalah mendorong siswa untuk mendapat hasil yang maksimal saat pembelajaran. Kemudian nilai indikator kemampuan pemecahan masalah matematis siswa terendah adalah pada indikator 4 yaitu 68 yaitu menarik kesimpulan dari hasil yang diperoleh, siswa kurang teliti dalam memberikan kesimpulan pada soal cerita yang menginginkan jawaban sesuai dengan masalah yang ada, mereka juga cenderung melupakan prosedur terakhir dan hanya menyelesaikan jawaban pada indikator 3. Dari nilai rata-rata tiap indikator tersebut, dapat disimpulkan bahwa hasil kemampuan pemecahan masalah matematis siswa kelas eksperimen di SMK PGRI 2 Palembang dikategorikan "Sangat baik".

Model pembelajaran probing prompting merupakan pembelajaran dengan cara guru menyajikan serangkaian pertanyaan yang sifatnya menggali dan menuntun sehingga terjadi proses berpikir yang mengaitkan pengetahuan setiap siswa dan pengalaman baru yang sedang dipelajari. Aktivitas semacam ini yang secara terus-menerus dilakukan dalam setiap pembelajaran, diharapkan akan dapat meningkatkan kemampuan siswa dalam hal memecahkan masalah. Hal ini sesuai dengan pendapat yang dikemukakan oleh Mustika dan Buana (2017:31) bahwa pembelajaranprobing prompting sangat erat kaitannya dengan pemeriksaan, mendorong atau menuntun. Pertanyaan-pertanyaan yang dilontarkan pada saat pembelajaran ini (probing question) dapat memotivasi siswa untuk memahami suatu masalah dengan lebih mendalam sehingga siswa mampu mencapai jawaban yang dituju. 
Pertama-tama siswa dihadapkan dulu pada suatu masalah, lalu siswa diberi waktu untuk mengemukakan pendapatnya mengenai solusi dari permasalahan tersebut, selanjutnya diberi LKS agar pembelajaran dengan model probing promptingsesuai dengan tujuan yang akan dicapai. LKS yang dirancang berdasarkan model ini secara langsung membimbing siswa menjawab masalah yang berhubungan dengan materi Peluang. Tugas LKS yang diberikan ini berupa serangkaian petunjuk melakukan aktivitas yang diarahkan untuk menemukan aturan-aturan tertentu, atau berupa soal-soal non-rutin yang berkaitan dengan keseharian siswa (kontekstual) yang harus diselesaikan secara kelompok. Dengan bekerjasama dalam kelompok, soal-soal non-rutin tersebut dapat diselesaikan dengan lebih baik, bila dibandingkan dengan bekerja secara individual.

Setelah siswa bekerjasama menyelesaikan LKS, guru secara langsung menunjuk salah satu siswa sebagai perwakilan kelompoknya untuk mempresentasikan hasil yang telah mereka dapat ke depan kelas, disinilah peran metode reward and punishment, guru memberikan reward bagi kelompok/ siswa yang maju dengan catatan prosedur serta hasil akhirnya benar dan tepat. Reward juga diberikan kepada siswa yang mampu menanggapi hasil presentasi kelompok lain dengan benar. Namun, bagi kelompok/ siswa yang kurang aktif di kelas akan diberikan punishment, sifat punishment disini adalah mendidik sekaligus memberikan efek jera kepada siswa agar lebih baik dalam pembelajaran selanjutnya, sehingga dengan diterapkannya metode ini akan membuat siswa berusaha semaksimal mungkin dalam proses pembelajaran. Hal ini sesuai dengan pendapat Shoimin (2014:157) bahwa reward sebagai alat pendidikan diberikan ketika seorang anak mencapai tahap sebuah perkembangan tertentu, atau tercapainya sebuah target. Metode ini bisa mengasosiasikan perbuatan dan kelakuan seseorang dengan perasaan bahagia, senang, dan biasanya akan membuat mereka melakukan suatu perbuatan yang baik secara berulang-ulang.

Pembelajaran yang digunakan pada kelas kontrol sama dengan kelas eksperimen, bedanya pada kelas kontrol hanya diterapkan model pembelajaran probing promptingsaja tanpa adanya pemberian reward and punishment. Selama pembelajaran siswa juga diberi serangkaian pertanyaan yang sifatnya menuntun dan menggali pola pikir siswa. LKS yang diberikan pun memuat langkah-langkah pembelajaran probing prompting. Namun disinilah terlihat perbedaannya, saat siswa ditunjuk untuk menanggapi hasil pengerjaan kelompok lain siswa tersebut 
ragu-ragu dan menoleh ke arah teman sekelompoknya, kejadian ini terjadi pada kelompok 6. Hal ini mengakibatkan banyak waktu terbuang sia-sia karena guru harus benar-benar mengarahkan siswa tersebut. Sesuai dengan pernyataan Shoimin (2014:159) model probing prompting masih memiliki kelemahan yaitu siswa akan merasa takut jika guru kurang bisa menciptakan suasana kelas yang akrab, karena pada umumnya siswa akan panik terlebih dulu jika akan diberikan pertanyaan. Selain itu, akan menghabiskan waktu jika dua atau tiga orang siswa tidak dapat menjawab pertanyaan yang diberikan.

Dengan menerapkan model pembelajaran probing prompting disertai pemberian reward and punishment diharapkan siswa mau belajar matematika, guru dapat memberikan soal pemecahan masalah dengan level yang lebih tinggi, lalu menyelesaikannya melalui kegiatan probing (menggali) dan prompting (mendorong), dilengkapi dengan pemberian reward (penghargaan) ataupun punishment (hukuman) terhadap hasil pekerjaan siswa. Tentunya dengan cara ini, diharapkan kemampuan pemecahan masalah siswa terhadap soal-soal level tinggi akan lebih baik. Sehingga diharapkan suatu saat siswa-siswa Indonesia dapat bersaing dengan negara lain dalam hal kemampuan pemecahan masalah matematika untuk soal-soal level tinggi.

\section{Kesimpulan}

Berdasarkan hasil analisis dan pembahasan dapat disimpulkan bahwa terdapat pengaruh reward and punishment pada pembelajaran probing prompting terhadap kemampuan pemecahan masalah matematis siswa kelas X SMK PGRI 2 Palembang. Hal ini dapat dilihat dari nilai rata-rata tes akhir Kemampuan Pemecahan Masalah Matematis siswa yang diberikan perlakuan model pembelajaran probing promptingdengan reward and punishment yaitu sebesar 86 dibandingkan dengan kelompok siswa yang diberi perlakuan dengan pembelajaran probing prompting saja yaitu sebesar 76 .

\section{Daftar Pustaka}

Harahap, E. R. \& Surya, E. (2017). Kemampuan Pemecahan Masalah Matematis Siswa Kelas VII dalam Menyelesaikan Persamaan Linear Satu Variabel. Jurnal Edumatica, Vol. 07, No. 01, 44-54.

Huda, M. (2014). Model-model Pengajaran dan Pembelajaran. Yogyakarta: Pustaka 
Pelajar.

Mustika, H. \& Buana, L. (2017). Penerapan Model Pembelajaran Probing Prompting terhadap Kemampuan Pemecahan Masalah Matematika Siswa. Jurnal MES (Journal of Mathematics and Science), Vol. 2, No. 2, 30-37.

Peraturan Menteri Pendidikan Nasional Republik Indonesia Nomor 22 Tahun 2006 Tentang Standar Isi Untuk Satuan Pendidikan Dasar Dan Menengah. Tersedia : https:/ / akhmadsudrajat.files.wordpress.com/ 2009/ 04/ permendiknas-no-22-ta hun-2006.pdf

Purnomo, H.\& Abdi, H.K. (2012). Model Reward dan Punishment (Persfektif Pendidikan Islam). Yogyakarta: Deepublish.

Prasetyo, A.H., Prasetyo, S.A., \&Agustini, F. (2019). Analisis Dampak Pemberian Reward dan Punishment dalam Proses Pembelajaran Matematika. Jurnal Pedagogi dan Pembelajaran, Vol. 2, No. 3, 402-409.

Shoimin, A. (2014). 68 Model Pembelajaran Inovatif dalam Kurikulum 2013. Yogyakarta: Ar-Ruzz Media.

Sugiyono. (2017). Model Penelitian Kuantitatif, Kualitatif dan R\&D. Bandung: Alfabeta.

Sumartini, T.S. (2016). Peningkatan Kemampuan Pemecahan Masalah Matematis Siswa Melalui Pembelajaran Berbasis Masalah. Jurnal Mosharafa, Vol. 5, No. 2, 148-158.

Torner, Schoenfeld, \& Reiss. (2007). Problem Solving in the Mathematics Classroom: the German Perspective. ZDM Mathematics Education (2007) 39:431-441.DOI 10.1007/ s11858-007-0040-5.

Triningsih, E. (2018). Pengaruh Pemberian Reward dan Punishment dengan Menggunakan Model Pembelajaran Kooperatif Terhadap Motivasi dan Hasil Belajar Matematika Siswa Kelas VII SMP Negeri 13 Makassar. Skripsi tidak diterbitkan. UIN Alauddin Makassar. 